\title{
Analysis of a Centreline Failure of a Lead Alloy Anode used in the Copper Electro-Winning Process
}

A. Elrefaey, Y. Gu, J.D. James, C. Kneen, I. Crabbe, J. Sienz

\section{Corresponding author:}

Dr Ahmed Elrefaey, Project Officer, ASTUTE 2020, College of Engineering, Swansea University, Bay Campus, Swansea, SA2 8PP, UK

\author{
Authors \\ Dr Yuchen Gu, Senior Project Officer, College of Engineering, Swansea University, Bay Campus, \\ Dr Jonathan James, Strategic Technology Manager, ASTUTE 2020, College of Engineering, Swansea \\ University, Bay Campus \\ Mr Chris Kneen, Process Director, Envirowales Limited, Rassau Industrial Estate, Ebbw Vale, \\ Blaenau Gwent, NP23 5SD \\ Mr Ian Crabbe, Managing Director, Royston Lead Limited, Pogmoor Works, Stock's Lane, Barnsley, \\ S75 2DS, UK \\ Professor Johann Sienz, Director of ASTUTE 2020, Director of Innovation and Engagement, College \\ of Engineering, Swansea University, Bay Campus \\ UK
}

\section{Highlights}

- Corrosion attack and propagation were surprisingly at the centre of the lead anode

- Extensive rolling of the anode is probably the main reason for exfoliation corrosion.

- Manganese contaminated electrolyte is deteriorating to the anode corrosion resistance

- The lead anode alloy was prone to exfoliation corrosion

- Methods were suggested to overcome the reason of failure

\begin{abstract}
Thousands of lead anodes are currently used in the electro-winning of copper across the globe. The corrosion and the electrochemical performance of these anodes significantly affect the economy of the process. Premature failure of anodes is often a problem for the commercial operators of tank houses. Recently, the authors were asked to advise on an unusual case where a lead alloy anode split at almost the centreline of the cross section. Different characterization techniques were employed to detect the cause of failure. The fractured samples were metallographically examined with an optical microscope and a Scanning Electron Microscope (SEM) equipped with Energy-Dispersive X-ray Spectroscopy (EDS) analysis. Different phase at the fracture surface were also identified by X-Ray Diffraction technique.
\end{abstract}

The failure mechanism of this anode appears to be manganese contaminated electrolyte attacking the anode perimeter, leading to initial corrosion sites and compounded by subsequent exfoliation corrosion through inter-granular attack and further formation of manganese dioxide. The established practice of 
producing lead alloy anodes via rolling confers beneficial properties to the finished anodes. However, the resulting elongated grains can in some cases, where the electrolyte is contaminated with elements that are prejudicial to stable oxide layer formation, cause susceptibility to exfoliation corrosion.

\section{Keywords:}

Exfoliation corrosion, lead anode, failure, electro-winning, microstructure

\section{Introduction}

Electrolytic cells are used in the copper electro-winning process to recover copper from its acidic sulphate solution and precipitate it at the cathode in the production cell. The multiple electrochemical cells are placed in a series which constitutes the tank house. The typical cell contains 20-50 pairs of anodes and cathodes in addition to one more anode in order to ensure plating of each cathode from both sides [1-2]. A schematic representation of the electrochemical cell is shown in Fig. 1.

Lead alloys are the preferred material for the anode because of their corrosion resistance to the sulphuric acid used in the copper electro-winning process. In addition to the electrical conductivity and the economic price of lead alloys, a continuous protective layer of lead dioxide is formed on the surface of the anode that is sufficiently conductive for circuit requirements and has the advantage of improving the corrosion resistance of the anode [3-6].

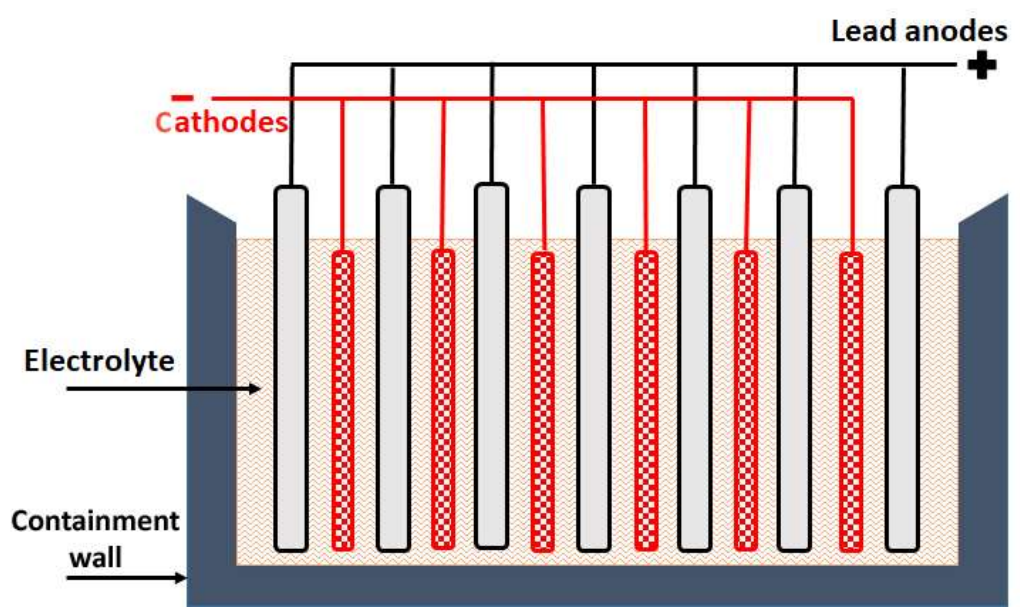

Fig.1 Schematic representation of anode and cathode alignment in the tank house

Since the introduction of the electro-winning technique into commercial use to produce copper, in the middle of the $19^{\text {th }}$ century [7], many improvements have been introduced to both the corrosion resistance and mechanical properties of lead anodes. Cast anodes were replaced by rolled anodes and antimonial alloys were superseded by calcium additions to the lead to increase the strength of the anode, while tin was found to have a beneficial effect on improving corrosion resistance, conductivity and oxygen evolution [4]. Nowadays, rolled $\mathrm{Pb}-\mathrm{Ca}-\mathrm{Sn}$ alloy is widely employed in industry owing to its unique combination of mechanical and electrochemical features [7]. This anode has a nominal weight composition of circa $0.07 \% \mathrm{Ca}$ and $1.5 \% \mathrm{Sn}$, with the remainder $\mathrm{Pb}$.

In spite of the improved characteristics of rolled lead anodes, corrosion problems and degradation still represent a great concern. A medium electro-winning tank house, from which the failed anode sample brought, contains 90 cells connected in a series. Each cell contains 60 anode/cathode pairs. The operating voltage may reach $\sim 2.0 \mathrm{v} /$ cell and cathodes current densities up to $320 \mathrm{~A} / \mathrm{m}^{2}$ [8]. Therefore, corrosion problems associated with lead anodes in the electro-winning tank house are significant to the manufacturer. The useful life of the anode is certainly prolonged by manufacturing high quality anodes, maintaining the correct operating conditions in the tank house, and performing the required 
maintenance. If these factors have been achieved, the anodes should last for 5 to 7 years before replacement since they are corroded by circa $0.5 \mathrm{~mm} /$ year [9-10].

When lead anode is in contact with sulphuric acid, a layer of $\mathrm{PbSO}_{4}$ is spontaneously formed. Owing to the anodic polarization, $\mathrm{PbSO}_{4}$ is transformed to a layer of $\mathrm{PbO}_{2}$. It is reported that the efficiency of the anode relying on the type of lead oxide formed at the anode interface. The dense and protective $\alpha \mathrm{PbO}_{2}$, formed close to the anode surface, is corrosion resistance while the $\mathrm{PbO}_{2}$, formed between the $\alpha \mathrm{PbO}_{2}$ and the electrolyte, is fluffy, loosely adherent, and has therefore less corrosion resistance than $\alpha \mathrm{PbO}_{2}$ [11-13].

The electrolyte in an electro-winning cell usually contains $40-50 \mathrm{~g} / \mathrm{L} \mathrm{Cu}^{2+}, 160-180 \mathrm{~g} / \mathrm{L} \mathrm{H}_{2} \mathrm{SO}_{4}$, and 1$3 \mathrm{~g} / \mathrm{L} \mathrm{Fe} \mathrm{kept} \mathrm{at} 50$ to $60^{\circ} \mathrm{C}$ [14-15]. Recently, a sample from a failed anode was received after less period of service than its normal life time in an electro-winning tank house overseas. The failure consisted of an unusual split close to the centre of the thickness of the anode. The objective was to investigate and determine the possible cause of failure.

\section{Experimental}

The limits for lead anode composition as given by anode manufacturer contains $\mathrm{Ca}(0.05-0.075), \mathrm{Sn}$ (1.4-1.6), and traces of other impurities. The failed anode sample was received as shown in Fig. 2. The sample was in sheet form, $140 \times 70 \mathrm{~mm}$ and $6 \mathrm{~mm}$ thick. There was general corrosion to the surface and some deep pitting corrosion to both sides. Additionally, the sample had split at almost the centre of the sheet as clearly shown in Fig. 2. The thickness of received sample has a clear indication that the sample has not in service for long time.
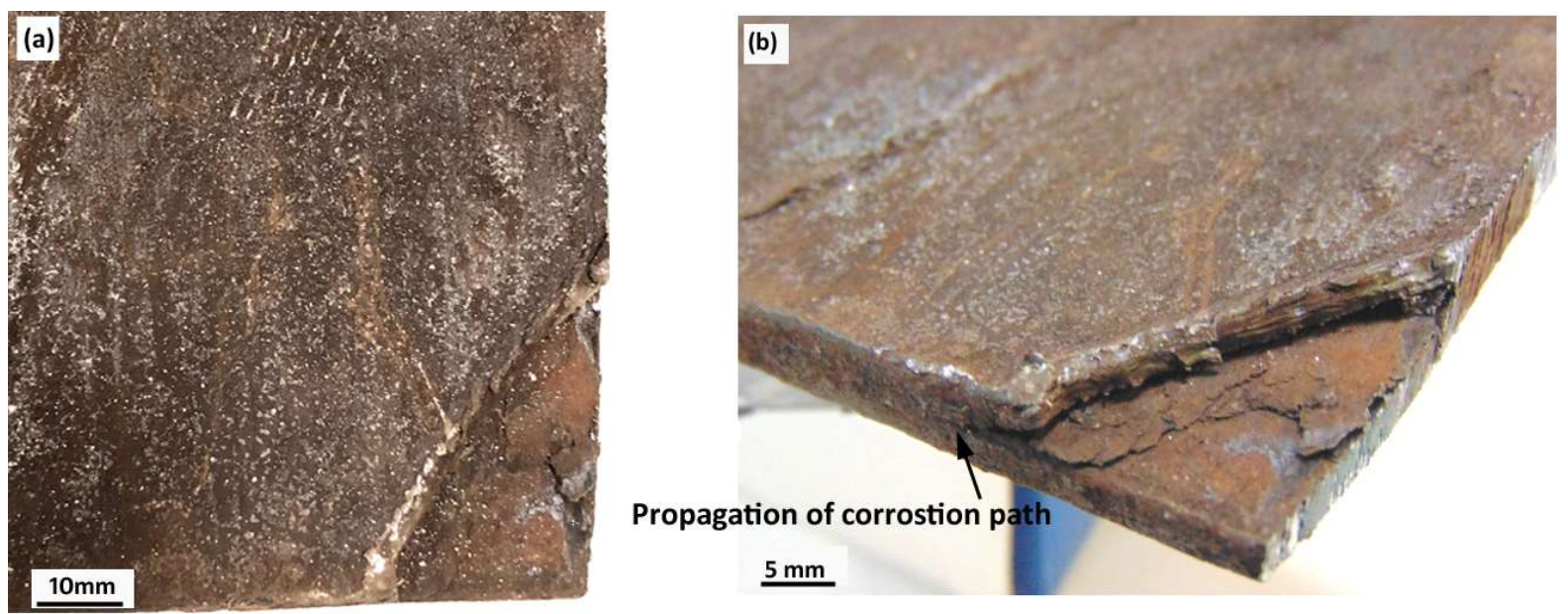

Fig. 2 Sample cut from failed anode (a) viewed perpendicular to anode surface; (b) illustration of the centreline failure path. The full thickness of the anode is $6 \mathrm{~mm}$.

Metallography of lead alloys requires great care as the material is soft and distortion to the microstructure can occur if silicon carbide paper is used. The problem of using silicon carbide is its hard particles which integrated in the microstructure during grinding which later on became difficult to remove at the successive polishing stages. Hence, the microstructure became unclear under the microscope. Therefore, alumina abrasive papers were used when preparing the sample for investigation under the microscope.

It is worth noting that owing to the lower crystallisation temperature of lead-calcium-tin anode, $63^{\circ} \mathrm{C}$ [9], unnecessary heat during sample preparation should be avoided. Furthermore, lead and lead alloys smear and blacken easily during etching. Therefore, etch-polishing alternated with examination under the microscope is mandatory. Etching was carried out using $40 \mathrm{ml}$ nitric acid $+30 \mathrm{ml}$ acetic acid +160 $\mathrm{ml}$ distilled water at $40^{\circ} \mathrm{C}$. 
The macrostructure of the sample surface was examined by optical microscope to analyse the surface features. Small sections from the surface and cross section were taken to continue the investigation by scanning electron microscopy and energy dispersive X-ray spectroscopy analysis to identify the microstructure and detect the elemental composition.

Phase identification of the samples were tested by the X-Ray Diffraction technique (XRD) at room temperature using $\mathrm{Cu} \mathrm{K} \alpha$ radiation $(\lambda=1.5406 \mathrm{~nm})$. The XRD data were collected from $20^{\circ}$ to $90^{\circ}(2 \theta)$ with a step interval of $0.03^{\circ}$. The resulting pattern was determined and compared with XRD pattern in the Crystallographic Online Database (COD).

\section{Results}

The lead anodes in the tank house were basically subjected to uniaxial tensile stress under its own weight. The magnitude of the stress is increasing from zero at the bottom surface of the anode to the maximum near the top. The anodes are removed from the cells every few months for cleaning and removal of unwanted scales. Therefore, the anodes are not subjected to high stress or fatigue.

Fig. 3 shows the SEM image and EDS analysis of the pit and general areas at the fracture surface, indicated by dashed areas. It is clear that the pit area (spectrum 1) mainly consists of lead and oxygen. Carbon is present but difficult to accurately detect because it is light metal and its signal may arises from the contamination deposited during analysis[16]. Sulphur is also existing but difficult to identify since the peak of sulphur overlaps with the peak of $\mathrm{Pb}[17]$. Therefore, lead oxides, lead sulphate, and lead carbonate are the possible existing phases. Meanwhile, the general area of the same surface, outside of pit area, showed a different structure. Manganese was detected by high percentage (spectrum 2) in addition to all elements present at the pit area. Taking into account the change in surface morphology outside the pit area, as shown in Fig. 3(c), there is a replacement of the lead oxides by manganese dioxide. The manganese dioxide layer had in some cases broken down, revealing the surface underneath containing the lead oxides (spectrum 3).

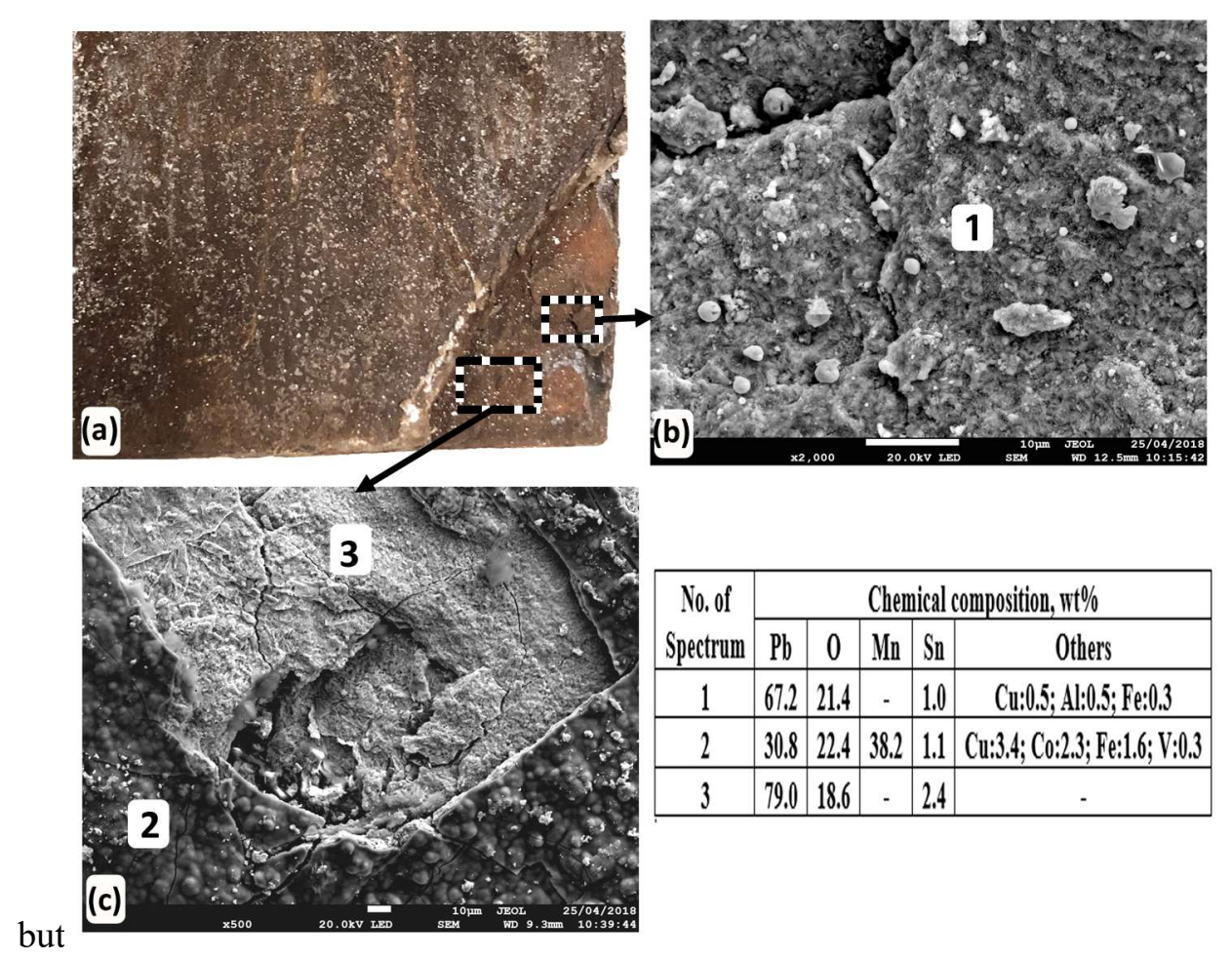

Fig. 3 (a) Failed region of anode, (b), and (c) SEM views of the two specified areas 
The XRD analysis gives information on which compounds or phase do exist at the different areas of fracture surface. Fig. 4 shows the peak pattern of the anode at the pitting area (a) and normal fracture surface area (b). The pattern showed a typical high crystallite material since the peaks are quite sharp. The formed phases have separated but closely allied crystallographic characteristics. Hence, it is quite hard to distinguish owing to the partially overlapping peaks. Through the matching with the data base, different corroded compounds were detected and confirmed. Pit area showed several peaks of phases such as $\mathrm{Pb}, \alpha \mathrm{PbO}_{2}, \mathrm{~Pb}_{3} \mathrm{O}_{4}, \mathrm{PbSO}_{4}, \mathrm{PbCO}_{3}$, and hardly peaks of $\beta \mathrm{PbO}_{2}, \gamma \mathrm{MnO}_{2}, \alpha \mathrm{MnO}_{2}$. While the normal surface of fracture area showed similar peaks to the one detected in the pit area but the manganese dioxide peaks were more prominent. It is worth mention that $\mathrm{MnO}_{2}$ showed abundant structural flexibility and existed in several crystallographic polymorphs such as $\alpha-, \beta-$, and $\gamma-\mathrm{MnO}_{2}$ [18]. The normal fracture surface area detected more peaks of the $\gamma-\mathrm{MnO}_{2}$. This result in agreement with our finding by EDS analysis.

Manganese is usually found in the cell as a result of its natural presence in the ore containing copper. This element is frequently reported to be harmful for the copper electro-winning process and should be removed in so far as is practicable [19-20]. The formation of manganese dioxide on top of the lead dioxide passivates the lead anode and inhibits the oxygen evolution reaction [21]. Furthermore, the manganese dioxide is formed as thick scales, which can easily become detached. These scales are damaging to the anode, could potentially cause an electrical short, and also increase the likelihood of cathode contamination. The above is demonstrated by the unattached manganese dioxide layer as shown in Fig. $3 \mathrm{c}$ and is detrimental to the electro-winning process.

Fig. 5 depicts the polished cross section investigation at the fracture surface towards the thinner area and the corresponding EDS analyses. Corrosion products containing lead, silicon, tin, iron, sulphur and copper oxides were accumulated at the edge of the sample, while the main content of the anode base material is lead, with few other elements. Investigation of the thicker area showed the formation of similar kinds of oxides.
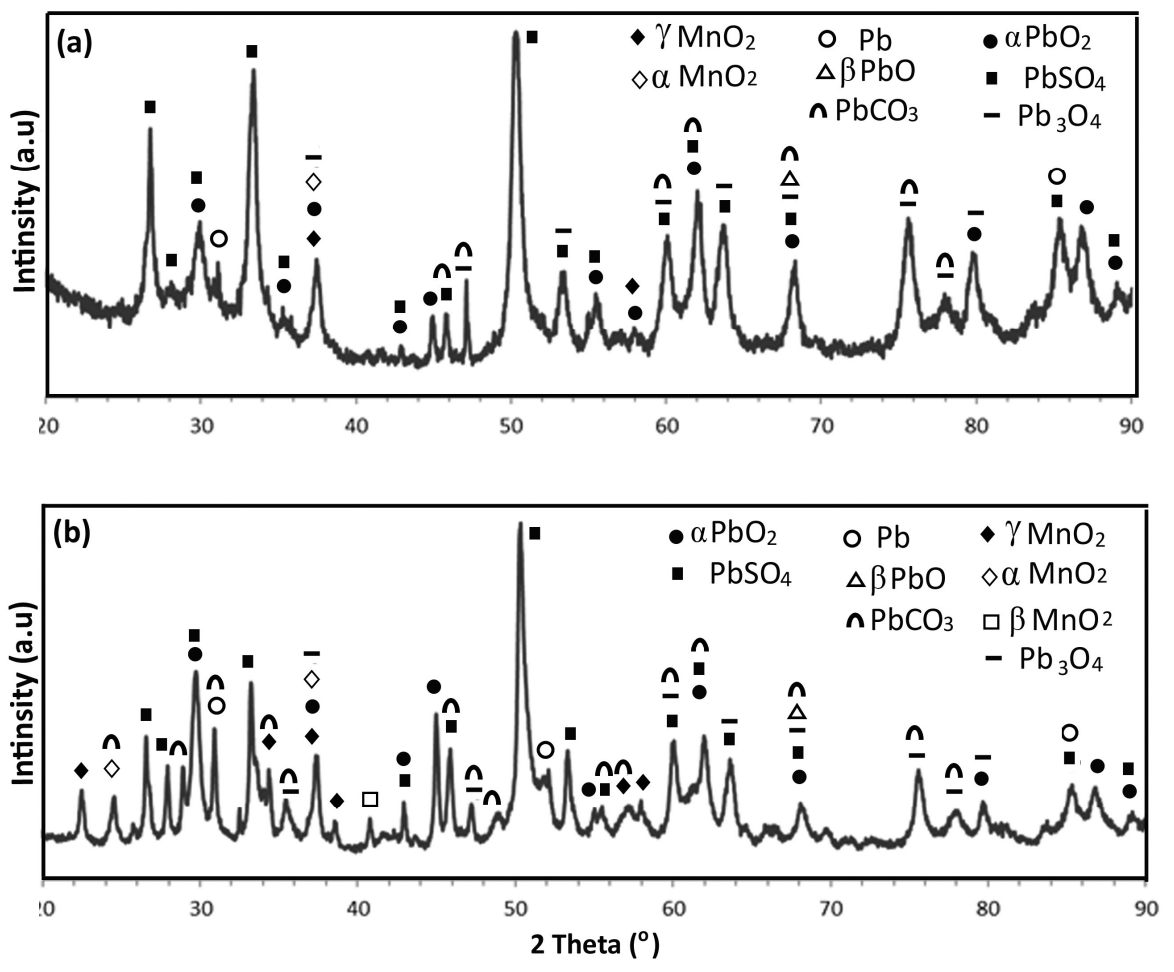

Figure 4: XRD patterns at pitting area (a) and normal fracture surface (b) 


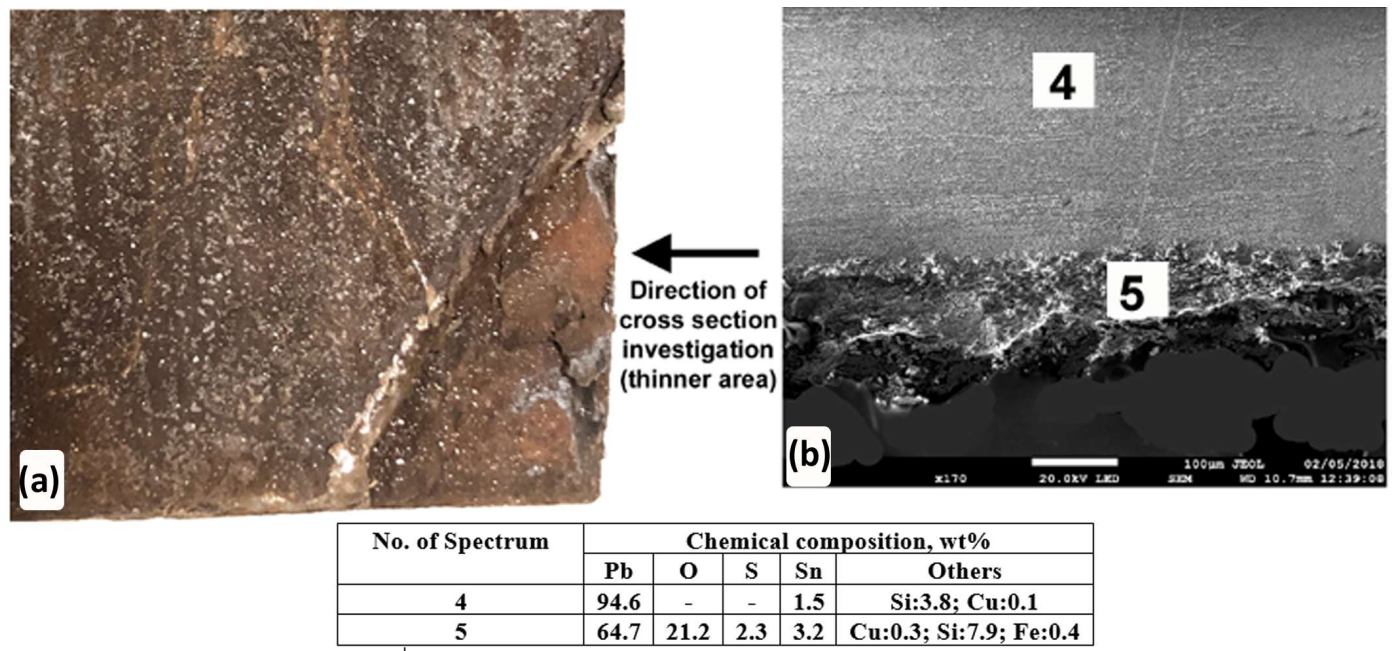

Fig. 5 Propagation of corrosion products at the centre of anode with EDS analyses

Fig. 6 illustrates the propagation of corrosion products at the centre of the lead anode before fracture. The macrostructure view corresponds to this crack path as previously seen in Fig. 2b. Corrosion products are composed of lead, silicon, and tin oxides (points 6,7 and 8 in Fig. 5). Slightly ahead of the tip of the corrosion, traces of corrosion products were also detected (point 8 ). This indicates that the anode centre is the preferable location of the corrosion path. No corrosion products were detected in the rest of the sample.
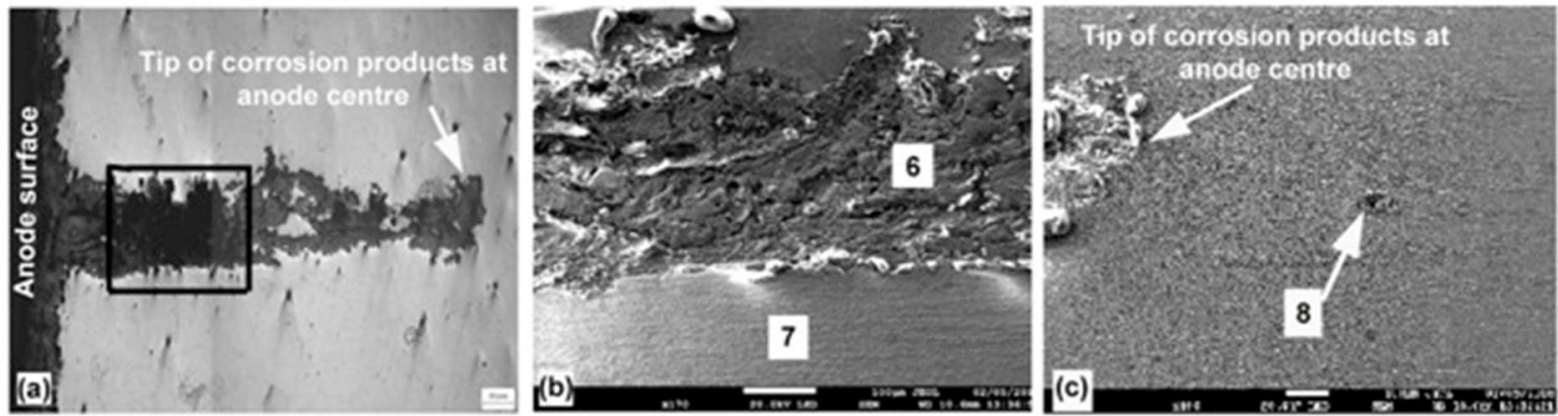

Fig. 6 Propagation of corrosion products at the centre of anode with EDS point analyses; (a) optical microstructure showing the corrosion products at the centre of anode; (b) SEM of the rectangular area in Fig. 5(a); (c) traces of corrosion products at the extension of corrosion tip.

It is noted that at the edge of the failed samples' cross section, there are obvious lifted surface layers as shown in Fig. 7. In these areas corrosion attack is taking place through the layer of the rolling structure, which results in the removal of layers of metal. This kind of corrosion attack is known as exfoliation corrosion and has previously been observed in aluminium alloys [22-25].
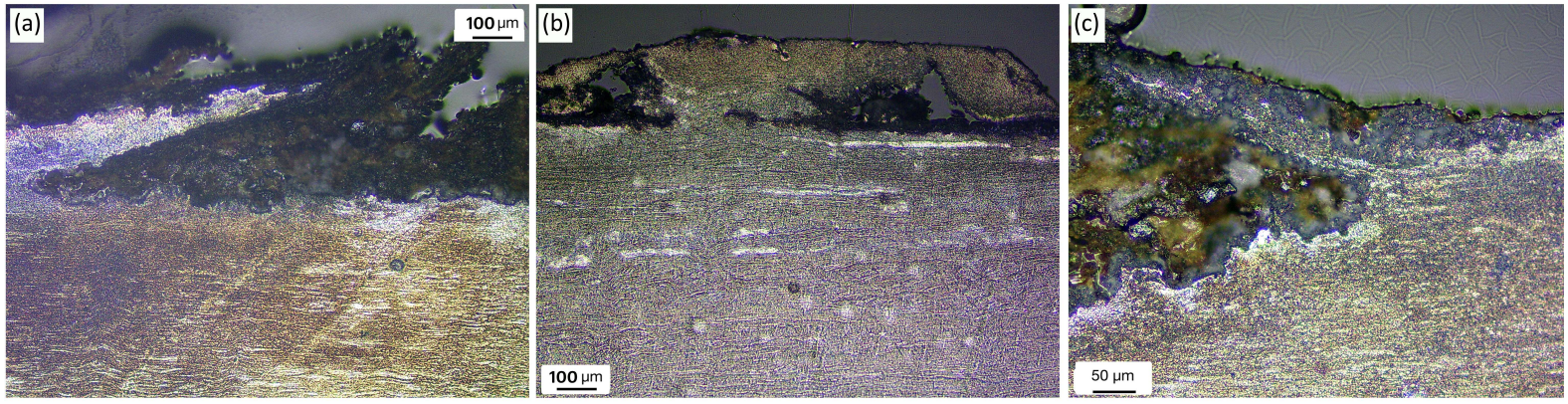

Fig. 7 Examples of lifted material areas at the edge of failed sample. 


\section{Discussion}

This type of corrosion is usually caused by an attack to the thin layer structure, which is characterized by high grain directionality. Exfoliation corrosion is normally initiated by galvanic corrosion inbetween the grain boundary and adjacent areas in the form of inter-granular corrosion [22]. The mechanism depends upon whether the precipitates are active or noble to the base material. The active precipitates are corroded and dissolved, while the noble ones cause the adjacent matrix to be attacked. The corrosion may continue to grow parallel to the surface along an inter-granular path. The resultant corrosion product possesses a larger volume than the original parent material; as a result, large stresses are generated at the inter-granular front that push the grains apart, promoting further attack [23].

The microstructure that is most susceptible to this type of attack is the layered or elongated grain structure. It is reported that the grain aspect ratio of the material is one of the main variables to be considered in respect of exfoliation corrosion [22,24-26]. The higher the grain aspect ratio, the greater the susceptibility to exfoliation attack. It was observed that the most aggressive attack was initiated at the centre of the plate [27]; this corresponds to the centre of the lead anode where the grains are more elongated, as previously observed in Fig. 6. More elongated grains are associated with a long and tortuous corrosion path, as well as slow development and consequently maximum value of the corrosion product force [28]. Fig. 8 shows the severe elongation of grains at the anode centre.

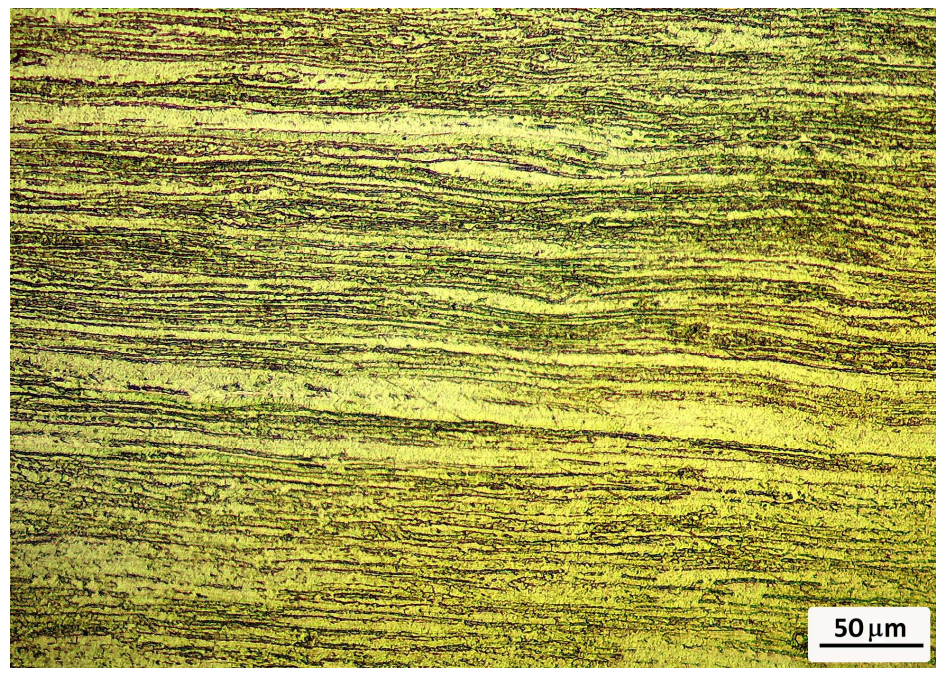

Fig. 8 Microstructure of anode at the centre.

The investigation into the failed split anode indicates that exfoliation corrosion appears to be the main cause of failure. The corrosion attack through the stretched grains, especially at the anode centreline, causes the grains to be pushed apart as corrosion products have a greater volume than the original uncorroded alloy. This creates stresses and forces that in turn cause leafing action of the grains, and an exfoliated sheet starts to appear as schematically illustrated in Fig. 9. 

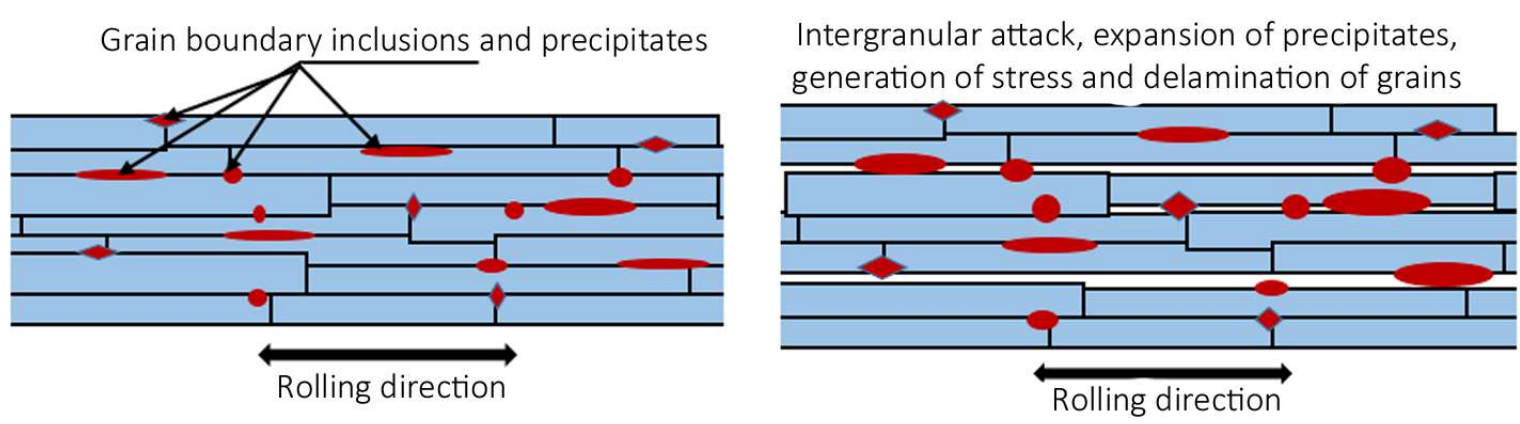

Fig. 9 Schematic illustration of exfoliation corrosion.

Although, as mentioned previously, anodes are rolled during their manufacturing process to improve their mechanical strength and corrosion resistance, the rolling processes of the plate increase the deformation and grain thinning toward the centre of the plate, which makes its microstructure more susceptible to exfoliation corrosion. Strains build up slowly in the grains with a high aspect ratio, and when the strains exceed the fracture strength of the materials, the grains start to break open and exfoliation starts [29].

Due, in all likelihood, to initial manganese related corrosion, the anode split and fractured at the centreline. Further corrosion attack by electrolyte containing manganese started to affect the surface of the split anode. As previously discussed, thick and brittle manganese dioxide was formed which sometimes broke down, causing further corrosion to the surface.

Extensive rolling of the anode is probably the main reason for the susceptibility of the material to exfoliation corrosion. To counter this, it would be possible to lower the aspect ratio of the grains by reducing the thickness of the initial slab that is the starting point for rolling, thereby avoiding significantly stretched grains in the final product. It is however noted that $\mathrm{SnCaPb}$ anodes are deliberately rolled with a reduction in excess of $70 \%$ for specific performance related reasons [30-31]. Where contaminants are able to be kept to low levels the benefits resultant from high rolling reductions can be realised, where manganese or other contaminants are expected to be present, lower rolling reductions could be considered.

Other factors also influence exfoliation corrosion. Alloying elements and precipitates at the grain boundaries have an effect on the galvanic corrosion between the boundary and grain interior. Much research has sought to describe the effect of alloying elements on the exfoliation corrosion of aluminium alloys [32-34]. Literature reports that most precipitates decrease the exfoliation resistance of aluminium alloys. Heat treatment conditions are thought to be important in exfoliation corrosion, because the treatment changes the microchemistry.

However, the authors have not yet come across previous research studies dealing with the exfoliation corrosion of lead alloys. In spite of this, the precipitates' effect is probably similar in lead alloys to that in aluminium alloys, although a detailed study on lead alloys would be required to confirm this. The environmental aspects and the composition of the electrolyte would be of fundamental importance to this study. A more in-depth understanding of the effect of these parameters on the exfoliation corrosion performance of lead alloys could help to decrease or eliminate this failure.

\section{Conclusions}

The established practice of rolling the lead alloy material confers beneficial properties to manufactured electro winning anode blades.

On a microstructural scale, highly elongated grains arise during rolling. The inter-granular paths between these grains can be one of the contributing factors to exfoliation corrosion. Other factors could include the exact alloy content of the anode material, the electrolyte chemistry and general 
tank house practice, all of which can enable the initial corrosion that then leads on to exfoliation corrosion.

However, it should be emphasized that exfoliation corrosion is rare in electro winning anodes, and the authors feel that due the limited extent of this phenomenon it would not be justified at this stage to abandon the practice of manufacturing anode blades via rolling.

It is suggested that tank house managers monitor the nature of corrosion of the anodes. In cases where examples of exfoliation do occur, the authors suggest mitigation action that could include modification of the electrolyte chemistry and/or other changes to tank house practice.

Should these changes not work and/or the problem was to be become more prevalent/widespread, the following could be investigated:

1. Research into coating the anode surface with a protective material that would not inhibit the oxygen evolution reaction.

2. Microstructural modification only of the perimeter of the anode (where the boundaries of the elongated grains are exposed to the anode surface) e.g. via localized heat treatment to reduce the grain aspect ratio.

3. As a last resort, altering the microstructure of the bulk of the anode could be considered. This could include altering the rolling ratio (e.g. by varying the thickness of the initial as-cast slab) and/or incorporating heat treatment of the as-rolled anode blade. Alternatively cast alloy anodes could be considered. Great care would be required here to ensure this approach would not result in other negative impacts on anode performance and life.

\section{Acknowledgement}

The ASTUTE 2020 (Advanced Sustainable Manufacturing Technologies) operation, supporting manufacturing companies across Wales, has been part-funded by the European Regional Development Fund through the Welsh Government and the participating Higher Education Institutions. The authors would like also to express their great appreciation to the Advanced Imagining of Materials (AIM) department at Swansea University for using their facilities and equipment.

\section{References}

[1]C. Coetzee, Characterizing the Role of Polyacrylamide Additives in Copper Electro-winning, MEng thesis, University of Stellenbosch, South Africa (2018).

[2[A. Shukla, Modeling and Measuring Electrodeposition Parameters Near Electrode Surfaces to Facilitate Cell Performance Optimization, MEng thesis, University of Utah, USA (2013).

[3] M. Moats, M. Free, A bright Future for Copper Electro-winning. JOM. 59(10), 34-36(2007).

[4] R.D. Prengaman, A. Siegmund, Improved Copper Electro-winning Operations using Wrought PbCa-Sn anodes. 4th International Conference COPPER 99-COBRE 99. 561-573(1999).

[5] M. Tunnicliffe, F. Mohammadi, A. Alfantazi, Polarization Behaviour of Lead Silver Anodes in Zinc Electro-winning Electrolytes. J. Electrochem. Soc. 159 (4), C170-C180 (2012).

[6] A. Felder, R.D. Prengaman, Lead Alloys for Permanent Anodes in the Nonferrous Metals Industry. JOM. 58(10), 28-31(2006).

[7] T. Kalliomäki, J. Aromaa, M. Lundström, Modeling the Effect of Composition and Temperature on the Conductivity of Synthetic Copper electrorefining electrolyte. Minerals 6(3), 59(2016). DOI: 10.3390/min6030059

[8] P.E. Wiechmann, S.A. Morales, P. Aqueveque, Improving Productivity and Energy Efficiency in Copper Electro-winning Plants, IEEE Transactions On Industry Applications, 46(2010).

[9] C.P. Camurri, M.J. López, A.N. Pagliero, F.G. Vergara, Deformations in Lead-Calcium-Tin Anodes for Copper Electro-winning, Mater. Charact. 47, 105-109(2001). 
[10] M. Clancy, C.J. Bettles, A. Stuart, N. Birbilis, The Influence of Alloying Elements on the Electrochemistry of lead Anodes for Electro-winning of Metals, A review, Hydrometall., 131-132: 144-157(2013).

[11] A. Mirza, M. Burr, T. Ellis, D. Evans, D. Kakengela, L. Webb, J. Gagnon, F. Leclercq, A. Johnston, Corrosion of Lead Anodes in Base Metals Electro-winning, J. South Afr. Inst. Min. Metall., 116, 533538(2016).

[12] R.D. Prengaman, H.B. Mcdonald, Stable Lead Dioxide Anode and Method for Production. US patent 4, 236,978. RSR Corporation, Dallas, TX(1980).

[13] O. Hyvarinen, The Effect of Silver and Cobalt on the Oxygen Evolution at Lead Anodes. Laboratoryof Process Metallurgy, Helsinki University of Technology, Otaniemi, Finland (1972).

[14] M. Schlesinger, M. King, K. Sole, W. Davenport., 2011, Extractive Metallurgy of Copper (5), Elsevier, Amsterdam.

[15] W. Cui, Effect and Interactions of Commercial Additives and Chloride Ion in Copper Electrowinning, MEng thesis, Missouri University of Science and Technology, Columbia (2014).

[16] J. Konopka, Options for Quantitative Analysis of Light Elements by SEM/EDS.2013, http://tools.thermofisher.com/content/sfs/brochures/TN52523_E_0713M_LightElement_H.pdf

[17] Buckwalter-Davies, M.J., 2013. Automated mineral analysis of mine waste. MSc. Thesis, Queens University, Ontario, Canada.

[18] Y. Dong, K. Li, P. Jiang, G. Wang, H. Miao, J. Zhang, C. Zhang, Simple Hydrothermal

Preparation of $\alpha$-, $\beta$-, and $\gamma-\mathrm{MnO}_{2}$ and Phase Sensitivity in catalytic Ozonation, RSC Adv., 3916739173: 4(2014).

[19] A. Elrefaey, Y. Gu, J.D. James, C. Kneen, I. Crabbe, J. Sienz, An Investigation of the Failure Mechanisms of Lead Anodes in Copper Electro-winning Cells, Eng. Failure analysis, 108, 104273 (2020).

[20] M. Clancy, C.J. Bettles, A. Stuart, N. Birbilis, The Influence of Alloying Elements on the Electrochemistry of lead Anodes for Electro-winning of Metals, A review, Hydrometall., 131-132: 144-157(2013).

[21] P. Yu, T.J. O'Keefe, Evaluation of Lead Anode Reactions in Acid Sulfate Electrolytes II. Manganese Reactions. J. Electrochem. Soc., 149, A558-A569 (2002)

[22] M. Posada, L.E. Murr, C.S. Niou, D. Roberson, D. Little, R. Arrowood, D. George, Exfoliation and Related Microstructures in 2024 Aluminum Body Skins on Aging Aircraft, Mater. Charact., 38, 259-272 (1997).

[23] Zhao, Xinyan, Exfoliation Corrosion Kinetics of High Strength Aluminum Alloys, Ph.D. dissertation, The Ohio State University, USA (2006).

[24] M.J. Robinson, N.C. Jackson, Exfoliation Corrosion of High Strength Al-Cu-Mg Alloys: Effect of Grain Structure. Br. Corros. J., 34, 45-49(1999).

[25] M.J. Robinson, Mathematical Modelling of Exfoliation Corrosion in High Strength Aluminium Alloys, Corros. Sci., 22, 775-790 (1982).

[26] D. McNaughtan, M. Worsfold, M.J. Robinson, Corrosion Product Force Measurements in the Study of Exfoliation and Stress Corrosion Cracking in High Strength Aluminium Alloys, Corros. Sci., 45, 2377-2389 (2003).

[27] M.J. Robinson, C. Jakson, The Influence of Grain Structure and Intergranular Corrosion Rate on Exfoliation and Stress Corrosion Cracking of High Strength $\mathrm{Al}-\mathrm{Cu}-\mathrm{Mg}$ Alloys. Corros. Sci., 41, 1013-1028(1999).

[28] M. Dollah, Investigation into the Propagation and Inspection of Stress Corrosion Cracks under Compressive Loading, Ph.D. dissertation, Cranfield University. (2007).

[29] P.L. Niu, W.Y. Li, N. Li,Y.X. Xu, D.L. Chen, Exfoliation Corrosion of Friction Stir Welded Dissimilar 2024-to-7075 Aluminum Alloys, Mater. Charact., 147, 93-100(2019).

[30] C. Camurri, C. Carrasco, Y. Maril, J. Peralta, Lead-Based Anodes for Copper Electro-winning: Effect of Grain Size on Mechanical and Anticorrosion Properties, Mater. Trans., 59, 620-624 (2018).

[301] C. Sommitsch, M. Ionescu, B. Mishra, E. Kozeschnik and T. Chandra, Optimal Deformation Hardening in Lead Base Anodes for Copper Electro-winning for an Appropiate Working Life, Mater. Sci. Forum, 879, 284-288(2016). 
[32] T. Marlaud, B. Malki, C. Henon, A. Deschamps, B. Baroux, Relationship Between Alloy Composition, Microstructure and Exfoliation Corrosion in Al-Zn-Mg-Cu alloys. Corros. Sci., 53, 31393149(2011).

[33] D.A. Wadeson, X. Zhou, G. E. Thompson, P. Skeldon, L. Djapic Oosterkamp, G. Scamans, Corrosion Behavior of Friction Stir Welded AA7108 T79 aluminum alloy. Corros. Sci., 48, 887897(2006).

[34] A.I. Karayan, K. Jata, M. Velez, H. Castaneda, On Exfoliation Corrosion of Alloy 2060 T8E30 in an Aggressive Acid Environment. J. Alloys Compd. 657, 546-558(2016). 